\title{
Study on the development of the desert pasture agrophytocenoses using a wide range of forage plants
}

\author{
Zinoviy Novitskiy ${ }^{1 *}$, Abdushukur Hamzayev ${ }^{1}$, Nizomiddin Bakirov ${ }^{2}$, and Abdulla Karimkulov ${ }^{3}$ \\ ${ }^{1}$ Research Institute of Forestry, 111104 Tashkent, Uzbekistan \\ ${ }^{2}$ State committee on forestry of the Republic of Uzbekistan, 100163 Tashkent, Uzbekistan \\ ${ }^{3}$ Gulistan State University, 120100 Gulistan, Uzbekistan
}

\begin{abstract}
The drained bottom of the Aral Sea covers an area of about 6 million hectares, of which 3.2 million hectares are located on the territory of the Republic of Uzbekistan. In addition to the fact that salt is spread from the drained bottom, dust and sand causing enormous damage to the environment, on the drained bottom there is a forest suitable area of 1.5 million hectares where it is possible to create desert shrub agrophytocenoses. The purpose of the work was to develop the most effective methods for creating desert agrophytocenoses on forest suitable types of bottom sediments of the dried bottom of the Aral Sea and the selection of desert forage plants to increase the productivity of the created pastures. Studies shown that when using focal, pasture protection and reclamation-fodder methods, as well as such fodder plants as teresken, boialich, keyreuk, it is possible to create pastures with a fodder capacity of up to 500 fodder units per hectare. This will increase the number of grazed animals by $20-30 \%$. The field of application of the results arising from this work are forest suitable types of bottom sediments of the drained bottom of the Aral Sea. The drained bottom of the Aral Sea is a reserve of a forage base for animals in the near future, which will give a new impetus to the development of animal husbandry in the Aral Sea region, and at the same time, fodder plants, fixing the soil of the drained bottom of the Aral Sea, will significantly improve the ecological situation in the Region.
\end{abstract}

\section{Introduction}

Deserts and semi-deserts in the Republic of Uzbekistan occupy 65\% of the territory, the main part of which is represented by treeless natural pastures and sand dunes. A low percentage of employment with forest plantations contributes to the development of wind erosion, which impedes the natural regeneration of pasture plants, causes low productivity of pastures and full or partial degradation of land [1-5].The problem, which today is in dire need of a solution, is especially important for Uzbekistan during the period of population growth (the population of Uzbekistan is about 34 million people). Uzbekistan has embarked on a course of providing itself with its own food products, including livestock products. To achieve these goals, an annual increase in the number of cattle and sheep is required. However, it is not so easy to do this due to the lack of animal feed. To create additional pastures on irrigated land is a difficult task, since they grow other crops of strategic importance to the state. And it becomes more and more difficult to water additional pastures every year, because there is a great shortage of water. In 2019-2020 all planted crops on the household plots of the local population died due to the scarcity of water for irrigation [6-8]. According to FAO and UNEP, $6,800,000 \mathrm{~km} 2$ of land on Earth was degraded due to overgrazing, 1,370,000 km2 due to the felling of trees for cooking and insulation of dwellings. It should be noted that, according to the sources mentioned, 5,500,000 km $2 \mathrm{of}$ the territory was degraded due to improper farming, as well as due to improper irrigation and watering [57].If until recently the development of animal husbandry took place through the development of still undeveloped pasture areas, now this reserve has been exhausted. However, in Uzbekistan there is one more reserve where it is possible to create pastures these are forest suitable types of bottom sediments of the drained bottom of the Aral Sea. People have the opinion that the drained bottom is solid sands and salt marshes. This is not at all the case. Unsuitable types of bottom sediments occupy an area of about $35 \%$, and the area on which desert pastures can be created is 1.5 million hectares [8]. In this region, with the correct use of scientific recommendations: Novitsky Z.B. - Recommendations on methods for creating pastures on the drained bottom of the Aral Sea (Tashkent, 2014), Recommendations for creating desert pasture agrophytocenoses on the drained bottom of the Aral Sea (Tashkent, 2017), Recommendations on the creation of pastures from fodder plants on weakly overgrown sandy sediments subject to deflationary processes on the drained bottom of the Aral Sea (Tashkent, 2020), it is possible to create pastures with a productivity of 400-500 fodder units per hectare [10-13]. It is assumed, that in the future this Region can become a supplier of feed for, which on May 18 at the

\footnotetext{
*Corresponding author: zinoviy.novitskiy@mail.ru
} 
75th UN General Assembly, the Aral Sea Region was declared a zone of environmental innovation and technology. The purpose of the study is to develop methods and select an assortment of desert forage plants for the creation of pasture agrophytocenoses on forest suitable types of bottom sediments of the drained bottom of the Aral Sea.

\section{Methods}

The studies were done on suitable types of bottom sediments of the drained bottom of the Aral Sea in the period from 2012 to 2020 . The technology of creating desert pastures was studied, an assortment of forage plants was selected, and the productivity of the created agrophytocenoses was taken into account. The work was carried out within the framework of the State programs for research projects: KHI - 5 - 012 - 2016; KHA - 7 - 026 - 2015; KX - A - KX 2018 - 110; I-BV-KH-2019-4.The objects of research were bottom sediments with chlorine less than $0.04 \%$ and according to the soil texture related to sandy loam and loamy soils [14]. The methods of creating desert shrub pastures were pasture protection, reclamation-fodder and focal forest plantations. The assortment of forage plants consisted of the following breeds:

gray teresken - Ceratoideslatens J.F. Gmel., chogon - Aelleniasubaphylla (C.A. Mey.) Aellen., keyreuk Salsolaorientalis S.G. Gmel., Boyalich -SalsolaarbusculaPall., Izen - Kochiaprostrata (L.) Schrad., In addition, the main forest-forming species is black saxaul - Haloxylonaphyllum (Minkw.) Lljin. Soil processing was performed with a chisel aggregated on a T-150K tractor, followed by sowing seeds or planting annual saplings. The aforementioned desert fodder plants, which form the basis of the created pastures, were tested. All work was carried out by setting up experiments in the field in 10-12 replication [50-54].

\section{Results and Discussion}

Let us consider the results of the above long-term studies on the creation of pasture agrophytocenoses using a wide range of desert forage plants. The targeted scientific research to test the possibility of growing an expanded range of forage plants on the drained bottom of the Aral Sea in order to create a desert pasture agrophytocenosis had not been done before. Therefore, this work was carried out, for the first time and in the spring of 2015; a series of experiments was laid to create desert pasture agrophytocenoses, in which 2 or more species of fodder plants participated. The experiment was carried out by a statistical method by sowing the seeds of forage plants. Throughout the growing season, soil moisture was studied and biometric measurements of emerging plant shoots were carried out. It is known that the moisture content of the soil has a great influence on the growth and development of plants, especially in the first year. .The still poorly developed root system in plants was in the horizon up to $15 \mathrm{~cm}$, so it is here that moisture plays a particularly important role. For sowing the seeds, the soil was treated with chisel, and the moisture was studied, both in the control also on the soil treated with chisel, for months [61-65].

Table 1. Soil moisture (\%) on the variants of the experiment on the creation of pasture agrophytocenoses (2015)

\begin{tabular}{|c|c|c|c|c|c|}
\hline \multirow{2}{*}{$\begin{array}{c}\text { Horizon } \\
\text { depth, cm }\end{array}$} & \multicolumn{5}{|c|}{ Months of research } \\
\cline { 2 - 6 } & April & May & June & July & September \\
\hline \multicolumn{5}{|c|}{ Option with soil treatment with chisel } \\
\hline $0-5$ & 6.80 & 3.60 & 2.56 & 1.98 & 1.12 \\
\hline $6-10$ & 7.34 & 5.06 & 3.45 & 2.21 & 1.75 \\
\hline $11-20$ & 10.08 & 8.38 & 6.12 & 3.24 & 2.22 \\
\hline $21-40$ & 21.77 & 22.40 & 17.65 & 15.46 & 12.41 \\
\hline $41-60$ & 26.60 & 28.93 & 26.71 & 23.45 & 22.34 \\
\hline \multicolumn{7}{|c|}{ The drained bottom was not subjected to soil treatment (control) } \\
\hline $0-5$ & 5.43 & 2.77 & 2.21 & 1.78 & 1.12 \\
\hline $6-10$ & 6.10 & 4.10 & 3.42 & 2.36 & 1.76 \\
\hline $11-20$ & 8.75 & 7.31 & 5.41 & 3.42 & 2.23 \\
\hline $21-40$ & 20.95 & 21.45 & 17.64 & 15.41 & 12.54 \\
\hline $41-60$ & 26.10 & 27.98 & 23.45 & 21.29 & 17.68 \\
\hline
\end{tabular}

In May 2015, $70.9 \mathrm{~mm}$ of precipitation fell, which is almost an average annual rate, and this made it possible to have a moisture content of 3.60-8.38\% in the $0-20 \mathrm{~cm}$ horizon (Table 1). In April, the soil moisture in the $0-5 \mathrm{~cm}$ horizon was $6.80 \%$, and at the end of the growing season in September it was only $1.12 \% .2015$ was favorable for the germination of seeds and the emergence of friendly seedlings of forage plants in the agrophytocenosis. However, in June and July, there was intense heat, the air temperature reached $50^{\circ} \mathrm{C}$, and on the surface of the earth it was more than $60^{\circ} \mathrm{C}$, which led to a burn of the teresken leaves that have not yet matured and other types of forage plants. Despite the fact that the leaves were burned, the root system of plant seedlings was alive [9]. In September, as a result of the autumn counts of the number of plants remaining after the summer heat, we excavated the root systems of the chogon and teresken. The state of root systems in 22 model plants was studied. It was revealed that the roots from sowing seeds in depth, on 
average, spread by $15-17 \mathrm{~cm}$ and horizontally by $10-12 \mathrm{~cm}$. Summer heat did not have a detrimental effect on the condition of the roots. They had been in a living state and, upon receiving additional moisture reserves due to winterspring precipitation, began their biological development [58-60].

Table 2. Accounting for the number of seedlings of forage plants $\left(\mathrm{pcs} . / \mathrm{m}^{2}\right)$ in the created desert agrophytocenoses on the drained bottom of the Aral Sea in 2015

\begin{tabular}{|c|c|c|c|c|c|}
\hline \multirow{3}{*}{$\begin{array}{l}\text { № } \\
\text { r/o }\end{array}$} & \multirow{3}{*}{$\begin{array}{l}\text { Plant } \\
\text { species }\end{array}$} & \multicolumn{4}{|c|}{ Counting time of the number of germinated seedlings by months } \\
\hline & & 13 May & 6 June & 30 July & 15 September \\
\hline & & $\begin{array}{c}\text { number of } \\
\text { germination }\end{array}$ & $\begin{array}{c}\text { number of } \\
\text { germination }\end{array}$ & $\begin{array}{c}\text { number of } \\
\text { germination }\end{array}$ & $\begin{array}{c}\text { number of } \\
\text { germination }\end{array}$ \\
\hline \multicolumn{6}{|c|}{ Chogon-teresken agrophytocenosis } \\
\hline 1 & Chogon & $21.1 \pm 0.73$ & $23.2 \pm 0.82$ & $23.7 \pm 0.70$ & $18.4 \pm 0.48$ \\
\hline \multirow[t]{2}{*}{2} & Teresken & $29.0 \pm 0.72$ & $31.3 \pm 0.62$ & $32.3 \pm 0.51$ & $27.6 \pm 0.60$ \\
\hline & Total: & $50.1 \pm 0.73$ & $54.5 \pm 0.70$ & $56.0 \pm 0.60$ & $45.0 \pm 1.08$ \\
\hline \multicolumn{6}{|c|}{ Boyalych -Keyreuk agrophytocenosis } \\
\hline 1 & Boyalych & $2.6 \pm 0.37$ & $3.9 \pm 0.34$ & $2.3 \pm 0.27$ & $1.0 \pm 0.17$ \\
\hline \multirow[t]{2}{*}{2} & Keyreuk & $3.0 \pm 0.33$ & $4.0 \pm 0.45$ & $2.3 \pm 0.26$ & $1.0 \pm 0.15$ \\
\hline & Total: & $5.6 \pm 0.35$ & $7.9 \pm 0.40$ & $4.6 \pm 0.27$ & $2.0 \pm 0.32$ \\
\hline \multicolumn{6}{|c|}{ Saxaul-Cherkez agrophytocenosis } \\
\hline 1 & Saxaul & $9.2 \pm 0.69$ & $11.0 \pm 0.64$ & $9.9 \pm 0.68$ & $6.6 \pm 0.59$ \\
\hline \multirow[t]{2}{*}{2} & Cherkez & $2.9 \pm 0.38$ & $5.0 \pm 0.44$ & $3.0 \pm 0.37$ & $1.5 \pm 0.20$ \\
\hline & Total: & $12.1 \pm 0.53$ & $16.0 \pm 0.54$ & $12.7 \pm 0.52$ & $8.1 \pm 0.79$ \\
\hline \multicolumn{6}{|c|}{ Chogon-keyreuk-boalych-teresken agrophytocenosis } \\
\hline 1 & Chogon & $24.8 \pm 1.05$ & $26.5 \pm 1.18$ & $24.6 \pm 1.0$ & $20.1 \pm 0.93$ \\
\hline 2 & Keyreuk & $1.8 \pm 0.29$ & $3.5 \pm 0.34$ & $1.9 \pm 0.18$ & $0.7 \pm 0.13$ \\
\hline 3 & Teresken & $28.5 \pm 0.96$ & $30.0 \pm 0.89$ & $27.5 \pm 0.90$ & $23.1 \pm 0.96$ \\
\hline \multirow[t]{2}{*}{4} & Boalych & $1.4 \pm 0.25$ & $2.6 \pm 0.42$ & $1.5 \pm 0.25$ & $0.7 \pm 0.15$ \\
\hline & Total: & $46.5 \pm 0.63$ & $62.6 \pm 0.70$ & $55.5 \pm 0.58$ & $44.6 \pm 2.17$ \\
\hline
\end{tabular}

As our experimental studies showed that the most favorable conditions for the growth of forage plants on the sandy loam plain of the drained bottom of the Aral Sea are found in teresken and chogon, less favorable in boyalych and keireuk. In the chogon-teresken agrophytocenosis, there are $45 \pm 1.08$ plants per $1 \mathrm{~m} 2$, while in the boalyche-keireuk agrophytocenosis there are only 2 plants (Table 2). To create desert shrub pastures, it is advisable to create multispecies agrophytocenoses, such as chogon-keyreuk-boalyche-teresken agrophytocenoses in which there are $44.6 \pm 2.17$ plants per $1 \mathrm{~m} 2$, which will allow for 4-5 years of growth to obtain productive pastures with a capacity of up to 500 feed units with 1 ha $[46,47,55.56]$. Determination of the stock of forage mass in the air-dry state in the aforementioned variants of the experiment in September 2017 showed that the capacity of pastures in the chogon-teresken agrophytocenosis was $562 \pm 12.4 \mathrm{~kg} / \mathrm{ha}$, in the boalyche-keireuk agrophytocenosis $-118 \pm 4.7 \mathrm{c} / \mathrm{ha}$., saxaul-Cherkez agrophytocenosis - $285 \pm 7.9$ centners / ha and in chogon-keyreuk-boalychev-teresken agrophytocenoses, respectively $522 \pm 12.7$ centners / ha. As we can see from the experimental material, despite the fact that in the first year there was a strong heat, and the ground mass was damaged, the preserved root system allowed the plants to recover due to the accumulation of moisture in the winter-spring period and form pastures with a good supply of forage mass for 3 the first year of their growth. $[48,49,56]$. In the process of conducting scientific research on the drained bottom of the Aral Sea, different methods of creating pastures were tested, but among them were used focal methods, as well as the creation of pasture protective forest and reclamation-forage belts (project KKH-A-KKH-2018-110). Forest reclamation science, developing measures that determine the possibility of creating pastures on a drained bottom, attaches great importance to the creation of pasture protective forest belts from black haloxylon The role of these bands in improving the microclimate elements when creating pastures cannot be overestimated. Being a biophysical body and an active element of desert landscapes, forest plantations reduce the wind speed, improve its turbulent exchange, regulate the processes of moisture evaporation from soil and growing vegetation, prevent deflationary processes, and significantly optimize the wind regime of interband spaces [15-25]. The accumulation, conservation and wise use of moisture is an important challenge facing foresters. In the summer, when intense heat is felt on the open part of the drained bottom, the reduction of evaporation under the protection of the strips plays a decisive role in the life of plants. The experiment showed that under the protection of forest belts, the daily moisture saving is $11.3 \mathrm{~mm}$. By months, under the protection of forest belts, daytime evaporation in April decreased by $31.3 \%$, nighttime by $46.4 \%$, in May by 25.3 and $30.6 \%$, and in JuneJuly by 26.0 and $48.7 \%$, respectively. Forest belts not only hold the soil together on the drained bottom, but by reducing evaporation, create additional moisture reserves in the soil for the growth of forage plants, which is especially important for the drained bottom, where the annual precipitation rate does not exceed $90 \mathrm{~mm}$ per year [26-36]. As our research has shown, haloxylon forest strips not only contribute to better growth and development of forage plants, but also significantly increase its nutritional value. Our zoo-technical analysis showed that under the protection of forest belts in fodder plants there is $1.0-2.7 \%$ more protein and protein than in open pastures of the drained bottom, and at the same time the amount of water is $2.4-17.0 \%$ higher, while fiber is less by $0.32-5.16 \%$ [41-45]. Consequently, under the protection of forest belts, food is more nutritious, and they are easier to eat by animals, because their moisture content is 
higher [43]. The placement of protective forest belts depends on the area of wind activity. The weaker the wind regime, the greater the distance between the stripes $(90-120 \mathrm{~m})$. In areas of strong wind activity, the distance between the stripes is $30-50 \mathrm{~m}$. The stripes are created in 3 rows. Seeds of such fodder plants as chogon, teresken, boyalich, keireuk, izen, etc. are sown in the spaces between strips. On the drained bottom of the Aral Sea, reclamation and forage strips are widespread, which can be located both in the spaces between the protective forest belts and in open spaces. Such strips are created mainly from forage plants and are placed in spaces between stripes with a distance of $20 \mathrm{~m}$ between them, i.e. 3-4 such strips are placed, and in the open areas of the drained bottom, reclamation and forage strips are placed 10 $\mathrm{m}$ from one another [37-39]. Fodder plants enter the fruiting stage within 2-3 years and under the influence of the wind the seeds are spread over the entire inter-strip space, thus creating enriched desert pastures. Studies have shown that in the 3 rd year after the creation of reclamation-forage strips in the inter-stripe spaces as a result of self-seeding, there were numbered 6-8 pcs plants per $1 \mathrm{~m}^{2}$. The technology for creating reclamation and forage strips is that the soil is processed in strips $1.5 \mathrm{~m}$ wide using a chisel or disc harrow. Seeds of shrubs and semi-shrubs are sown along the loosened strips. From the assortment of plants tested, the best results on the accumulation of phytomass were obtained in chogon, keireuk and teresken. The seeds of these breeds are sown in autumn, winter and spring after collecting and determining the purity of the seed heap and laboratory germination. Seeding is done with tine harrows followed by rolling. At the same time, a mixture of keireuk and teresken seeds can be sown, and it is better to sow chogon seeds in pure rows $[40,66,67]$. The drained bottom of the Aral Sea is represented by different types of bottom sediments from soils of light granulometric composition to heavy ones, and to varying degrees of salinity up to highly saline soils. We studied one of the promising methods of creating pastures - this is the focal method, the essence of which is that 7-10 sites (foci) measuring $2 \times 2$ meters are placed on 1 hectare of the drained bottom. On these sites, seeds of fodder plants are sown, which enter the fruiting stage for 2-3 years, and their seeds under the influence of the wind are spread throughout the territory, forming a continuous cover of fodder plants (pastures). Studies have shown that already in the 5 th year, the entire territory where foci of forage plants were laid was covered with forage plants, which subsequently gave seeds, and their distribution proceeded exponentially. The stock of fodder in the air-dry state per 1 hectare of such pastures was $5060 \mathrm{~kg}$, which amounted to 2176 fodder units $(\mathrm{kg})$. Created forest and forage plantations play a very important role on the drained bottom of the Aral Sea, where vegetation grows in very small quantities. This is especially important at the present time, when a huge emission of carbon dioxide into the atmosphere, and, accordingly, a decrease in oxygen, lead to a warming of the Earth's climate. In 1997, Uzbekistan signed the Kyoto Protocol, which entered into force in 2005. It is impossible to fulfill the main provisions of the Kyoto Protocol without vegetation. Forests counteract the greenhouse effect by working for the entire Planet [50]. In this regard, forest plantations and pastures created from forage plants on a drained bottom are priceless. They are a biological factor that can return the population of the Aral Sea region to a healthy life, solve the problem of providing animals with food, and also minimize the occurrence of deflationary processes, which has a positive effect on air purity, reducing carbon dioxide and increasing oxygen [56]. The creation of desert shrub pastures on the drained bottom of the Aral Sea is of ecological, economic and social importance.

- ecological. Plants with their roots, including fodder ones, hold the soil together and thereby prevent their destruction, which leads to a decrease in the occurrence of deflationary processes. Accordingly, less salt and dust are carried away, which then settle on irrigated lands and reduce their fertility, while the yield of agricultural crops stabilizes; the air becomes cleaner, which people breathe, which will have a positive effect on the gene pool of the local population.

- economic. The suitable types of bottom sediments of the drained bottom are a reserve for creating a forage base for animal husbandry in the Region. Methods have already been developed for creating desert agrophytocenoses on a drained bottom using a wide range of forage plants. Correctly selected assortment of forage plants in the creation of desert agrophytocenoses will make it possible to increase the capacity of pastures to 500 forage units per hectare. The number of grazed animals can be increased by $20-30 \%$ in comparison with natural pastures and, accordingly, the population of the country can be provided with livestock products.

- social. Scientists of our institute see their task also in the fact that by creating multicomponent pastures, the local population will develop animal husbandry, because they will be provided with food. People will unite in groups and graze their animals on the pastures of the drained bottom of the Aral Sea, which are already being created by forestry enterprises according to our recommendations. If these groups of people (communities), who will graze 40-50 cows, are provided with mini-factories for processing dairy products, and which once a week the machine will pick up for sale through the distribution network, and next week bring money for the delivered dairy products, then the local population will come to grips with animal husbandry. People will feel that their work is appreciated and for the money they earn they will be able to provide their families with everything they need, then the whole family will start breeding own domestic animals. The results of work on the creation of pasture agrophytocenoses will make it possible to organize a movement for the development of animal husbandry on the drained bottom of the Aral Sea. At first it will be Initiative, which will then turn into Movement. Thus, we will be able to solve social issues of the local population through the creation of pasture agrophytocenoses on the drained bottom of the Aral Sea.

\section{Conclusions}

On the basis of the research results, it can be argued that on forest suitable types of bottom sediments of the drained bottom of the Aral Sea, it is possible to create desert pasture agrophytocenoses using a wide range of forage plants. To 
achieve this goal, it is advisable to use the focal method of creating pastures, as well as methods of pasture protection and reclamation-fodder afforestation, which will increase the fodder productivity of the territory, and increase the number of grazed animals by $20-30 \%$.

\section{References}

1. N.J.Bakirov, Z.B. Novitsky, A.Kh. Khamzaev, Prospects for the revival of the drained bottom of the Aral Sea, $J$. Ecological Bulletin of Uzbekistan 9, 6-7 (2019)

2. N.J. Bakirov, Z.B. Novitskiy, A.Kh. Khamzaev, Growing saxaul seedlings in forest nurseries in the Republic of Karakalpakstan, International Scientific and Practical Conference dedicated to the 65th anniversary of the work of the Department of Plant Production of the Izhevsk State Agricultural Academy in Udmurtia, Izhevsk pp. 359-364 (2019)

3. N.j. Bakirov, Z.B. Novitsky, A.Kh. Khamzaev, Seedlings of saxaul in forest nurseries, J. Agriculture of Uzbekistan 2, 31-32 (2020)

4. N.J. Bakirov, Z.B. Novitsky, A.Kh. Khamzaev, Forest plantations on the drained bottom of the Aral Sea, Forest Journal 374(2), 51-59 (2020)

5. N.J.Bakirov, Z.B. Novitsky, A.Kh..Khamzaev, F.K. Auezov, The ecological role of forest plantations on the drained bottom of the Aral Sea, J. Agro Ilm 4(67), 83-85 (2020)

6. N.J. Bakirov, A.Kh. Khamzaev, Z.B. Novitskiy, F.K. Auezov, Innovative methods of afforestation of the drained bottom of the Aral Sea, J. Agro Ilm 5(68), 67-69 (2020)

7. N.J. Bakirov, Z.B. Novitsky, A.Kh. Khamzaev, Creation of basic forest nurseries in the Aral Sea region, J. Ecological Bulletin of Uzbekistan 5(229), 16-17 (2020)

8. N.J. Bakirov, A.Kh. Khamzaev, Z.B. Novitskiy, G.Kh. Atadzhanova, Creation of pastures by the link method on the drained bottom of the Aral Sea, J. Agro Ilm 70,82-83 (2020)

9. N.J. Bakirov, A.Kh. Khamzaev, Z.B. Novitskiy, How to create a seed base of saxaul in the Aral region, J. Agriculture of Uzbekistan 12, 37-38 (2020)

10. A.V. Borovkov, K.J. Ustemirov, Yu.T.Tairbergenov, Z.B. Novitsky, Methods of afforestation of the drained bottom of the Aral Sea, Materials of the Forest Forum, Astana (2015)

11. A.V. Borovkov, K.J. Ustemirov, Yu.T. Tairbergenov, Z.B. Novitsky, Forest reclamation of the drained bottom of the Aral Sea, In the book: Collection of annotated reports (works) on the project "Preservation of forests and increase in forest cover territory of the republic 2007-2014", pp. 232-239 (2017)

12. A.V. Borovkov, K.J. Ustemirov, Yu.T. Tairbergenov, Z.B. Novitskiy, Recommendations for the creation of permanent forest seed plots on the drained bottom of the Aral Sea, In the book: Collection of recommendations developed within the framework of the project: Preservation of forests and increasing the forest cover of the territory of the republic, Astana, pp.110-142 (2014)

13. A.V. Borovkov, K.J. Ustemirov, Yu.T. Tairbergenov, Z.B. Novitsky, V.V. Kopytkov, Recommendations for growing planting material in forest irrigated nurseries. In the book: Collection of recommendations developed within the framework of the project: Preservation of forests and increasing the forest cover of the territory of the republic, Astana, pp.144-174 (2014)

14. A.V. Borovkov, K.J. Ustemirov, Yu.T. Tairbergenov, Z.B. Novitsky, Forest reclamation of the drained bottom of the Aral Sea, J. Ecological Bulletin of Uzbekistan 6, 22-25 (2016)

15. L.S. Gaevskaya, Karakul-breeding pastures of Central Asia, Science, Tashkent (1971)

16. A.A. Danilin, Z.B. Novitsky, T.A. Yurkevich, Pastures on fixed sands, J. Sheep Breeding 4, 31-33 (1087)

17. A.L. Danilin, Z.B. Novitskiy, Influence of pasture protective forest belts on the harvest of wormwood in the South-Eastern Kyzyl Kum, Increasing the production of agricultural products in the light of the tasks arising from the country's food program, Tashkent, pp. 105-107 (1983)

18. A.L. Danilin, Z.B. Novitsky, Moisture content of pasture plants in inter-lane spaces, Increasing the production of agricultural products in the light of the tasks arising from the food program of the country, Tashkent, pp.107-109 (1983)

19. A.L. Danilin, Z.B. Novitskiy, Forage properties of herbaceous plants in inter-lane spaces, Scientific Conference on Implementation of the Food Program, Tashkent, pp. 17-18 (1984)

20. N.E. Koksharova, Z.B. Novitsky, Self-overgrowing by vegetation of the drained bottom of the Aral Sea, Reports of the Academy of Sciences of the UzSSR 4, 54-56 (1988)

21. N.E. Koksharova, Z.B. Novitsky, Protective afforestation on the drained bottom of the Aral Sea, J. Forestry 5, $12-$ $14(1988)$

22. N.E. Koksharova, Increasing the productivity of pastures in the desert zone of Central Asia, Survey information, State Committee for Forestry, Center for Scientific and Technical Information Bureau, Moscow (1985)

23. A.A. Leontiev, L.E. Rodin, Narrow-band method of improving desert pastures of Uzbekistan with crops of black saxaul, Science, Tashkent (1967)

24. I.F. Momotov, D.K. Saidov, K.T. Fayziev, Creation of artificial phytomeliorants against the background of sandaccumulating furrows, Science (1973) 
25. N.T. Nechaeva, N.N. Pelt, Forage base for sheep breeding in the desert zone of Central Asia and Kazakhstan. On Sat, Natural conditions, animal husbandry and forage base of deserts, Ashgabat (1963)

26. Z.B. Novitskiy, Influence of pasture protective forest belts on snow deposition, J. Forestry 1, 43-45 (1987)

27. Z.B. Novitsky, T.A. Yurkevich, The influence of protective plantations on the microclimate of pastures in the desert zone, J. Uzbek Biological Journal 2, 36-39 (1987)

28. Z.B. Novitsky, Increase of pasture productivity under the influence of forest belts in desert conditions, Reports of the Academy of Sciences of the Uzbek SSR 12, 42-44 (1987)

29. Z.B. Novitsky, Growth of desert rocks on the sandy plain of the former Fisherman's Bay of the Aral Sea, Uzbek Biological Journal 6, 43-46 (1990)

30. Z.B. Novitskiy, Accumulation of the phytomass of desert rocks depending on agrotechnical methods on the drained bottom of the Aral Sea, Proceedings of SredazNIILH 29, 123-127 (1991)

31. Z.B. Novitsky, Cultivation of forage plants on the former bottom of the Aral Sea, J. Agriculture of Uzbekistan 10(11), 26-27 (1992)

32. Z.B. Novitsky, Accumulation of phytomass in saxaul and Cherkez on the drained bottom of the Aral Sea, Reports of the Academy of Sciences of the Republic of Uzbekistan 8, 54-56 (1994)

33. Z.B. Novitsky, M.Sh. Ganiev, Seed renewal of black saxaul on the drained bottom of the Aral Sea, 25 years of Nukus University, Nukus (2001

34. Z.B. Novitsky, The role of vegetation in relief formation on the drained bottom of the Aral Sea, International Meeting on the Problem of Soils, Tashkent (2003)

35. Z.B. Novitsky, Forest revives the drained bottom of the Aral Sea, J. Agriculture of Uzbekistan 10, 36-37 (2003)

36. Z.B. Novitsky, A new approach to forest reclamation work on the drained bottom of the Aral Sea, Problems of rational use of land resources, Tashkent, pp. 50-53 (2007)

37. Z.B. Novitsky, Pasture protective afforestation on the drained bottom of the Aral Sea, Biosphere territories of Central Asia as natural heritage, Cholpon-Ata, Bishkek, pp.54-56 (2009)

38. Z.B. Novitsky, K.Sh. Tadjibaev, L.V. Nikolai, Desert plant species selected for testing in the project areas, Publishing House Tashkent, Tashkent (2009)

39. Z.B. Novitsky, Phytomelioration in the southern part of the Aralkum desert, Aralkum - and man - made desert, Germany, pp.387-406 (2011)

40. Z.B. Novitsky, V.T. Vukherer, Saksaul on the drained bottom of the Aral Sea, Uzbek Ecological Journal 9, 24-24 (2011)

41. Z.B. Novitskiy, The role of pasture protective forest belts in the formation of the microclimate of interband spaces, International Meeting on Increasing Productivity and Improving the Use of Rangelands in the Semi-desert and Desert Zones of the Republic of Central Asia and Kazakhstan, Tashkent (1982)

42. Z.B. Novitskiy, Influence of pasture protective forest belts on the yield of roofing fire and bulbous bluegrass, XI Scientific and Practical Conference on Intensification issues, Tashkent (1983)

43. Z.B. Novitsky, Nutritional value of pasture plants, J. Agriculture of Uzbekistan 1, 34 (1984)

44. Z.B. Novitsky, Pasture protective forest belts in the desert, J. Sheep Breeding 9, 26-28 (1984)

45. Z.B. Novitskiy, A.L. Danilin, Influence of pasture protective forest belts on the productivity of desert pastures, International Conference on Implementation of the Food Program, Tashkent (1984)

46. Z.B. Novitsky, The drained bottom of the Aral Sea is a reserve for receiving feed, J. Agro Ilm 2(3) 45-46 (2015)

47. Z.B. Novitsky, Pastures on the drained bottom of the Aral Sea, Ecological Bulletin of Uzbekistan 4, 44-46 (2014)

48. Z.B. Novitsky, Creation of permanent forest seed plots on the drained bottom of the Aral Sea, Ecological Bulletin of Uzbekistan 4, 44-46 (2014)

49. Z.B. Novitsky, K.Zh. Ustemirov, Development of a Unified System of Forest Reclamation Development of the Dried Aral Sea Day, Ecological Bulletin of Uzbekistan 11, 33-36 (2014)

50. Z.B. Novitsky, No forest - plant, little forest - take care, a lot of forest - save, Ecological Bulletin of Uzbekistan 3 , 50-52 (2015)

51. Z.B. Novitsky, Forest plantations on the drained bottom of the Aral Sea, Ecological Bulletin of Uzbekistan 10, 31$36(2015)$

52. Z.B. Novitsky, Permanent forest seed plots of gray teresken in the Aral Sea region, J. Agro Ilm 4, 47-48 (2016)

53. Z.B. Novitsky, Adaptation measures implemented at the level of landscapes, aimed at increasing the resilience of communities to climate change: Issues of adaptation to climate change in Karakalpakstan, UNDP Newsletter 3, 1$4(2016)$

54. Z.B. Novitsky, Creation of pasture agrophytocenoses on the drained bottom of the Aral Sea, J. Agro Ilm 1(45), 3738 (2017)

55. Z.B. Novitsky, Permanent forest seed plots of chogon (Aellinia subaphylla) on the drained bottom of the Aral Sea, J. Agro Ilm 2(46), 71-72 (2017)

56. Z.B. Novitsky, Pasture agrophytocenoses on the drained bottom of the Aral Sea, Ecological Bulletin of Uzbekistan 2, 20-22 (2017)

57. Z.B. Novitsky, Forest reclamation is part of a set of measures aimed at improving the ecological situation on the drained bottom of the Aral Sea, Ecological Bulletin of Uzbekistan 4, 37-42 (2017) 
58. Z.B. Novitsky, Aral crisis: solutions, Scientific-practical Conference on Forest Science of Kazakhstan: Achievements, Problems and Development Prospects, KazNIILH, Shchuchinsk (2017)

59. Z.B. Novitsky, Desert forest on the drained bottom of the Aral Sea, Ecological Bulletin of Uzbekistan 3, 25-28 (2018)

60. Z.B. Novitsky, Methods of creating pastures on the drained bottom of the Aral Sea, J. Agro Ilm 4(54), 33-34 (2018)

61. Z.B. Novitsky, Afforestation of saline soils on the drained bottom of the Aral Sea, Ecological Bulletin of Uzbekistan 8, 33 (2018)

62. Z.B. Novitsky, N.Zh. Bakirov, A.Kh. Khamzaev, Forest plantations in the revival of the drained bottom of the Aral Sea, 2020-International virtuol Forum on Greeningandland Degradation Neutraity in Drylan, Germany (2020)

63. G.A. Sergeeva, Z.Sh. Shamsutdinov, L.S. Gaevskaya, R.M. Chalbash, Creation of pasture protection forest belts from black saxaul, Science, Tashkent (1975)

64. K.J. Ustemirov, Z.B. Novitskiy, Unified system of forest reclamation development of the drained bottom of the Aral Sea, Forest Forum, Astana (2015)

65. A.Kh. Khamzaev, Z.B. Novitsky, Center for growing seedlings of desert plants, International Conference on Joint Actions to Mitigate the Consequences of the Aral Catastrophe: new approaches, innovative solutions and innovations, Tashkent (2018)

66. F. Hufler, Z.B. Novitskiy, Green shield of the drained bottom of the Aral Sea, Brochure-Tashkent, Tashkent (2003)

67. Z.Sh. Shamsutdinov, N.T. Nechaeva, Creation of long-term pastures in the arid zone of Central Asia, Science, Tashkent (1975) 